PRODUCTION

ENGINEERING ARCHIVES
2015, Vol. 9, No 4, pp 17-20

ISSN2353-5156 (print version)

ISSN2353-7779 (online version)

\title{
The machines maintenance conditions assessment in the plastic industry
}

\author{
Stanisław Borkowski ${ }^{1}$, Renata Stasiak-Betlejewska ${ }^{2}$ \\ ${ }^{1}$ Institute of Production Engineering, Faculty of Management, Czestochowa University of Technology, Armii Kajowej 19B, 42-200 Często- \\ chowa, Poland, tel. +48 343250 333, e-mail: bork@zim.pcz.pl \\ ${ }^{2}$ Institute of Production Engineering, Faculty of Management, Czestochowa University of Technology, Armii Kajowej 19B, 42-200 Często- \\ chowa, Poland, tel. +48 343250 333, e-mail: bork@zim.pcz.pl
}

\begin{abstract}
The purpose, methodology, main findings, the originality of the subject area (research), way of using. The main research analysis purpose is a presentation, an assessment and an interpretation of the research findings on the machines maintenance conditions in the plastic industry. The research analysis was carried out with applying Technology ABC method and TPM coefficients calculations connected with Techno pak machine components maintenance. The research was carried out in the chosen manufacturing enterprise of the plastic industry. Research findings interpretation results have been introduced in the analyzed enterprise in the form of the manufacturing processes improvement.
\end{abstract}

Key words - manufacturing, plastic industry, machine maintenance, TPM coefficients, Technology ABC method

\section{Introduction}

The manufacturing process in the plastic industry is related to constant assessment of the machines maintenance conditions. Results of this assessment influence on the final product quality since the quality is determined by the production processes evaluation and its improvement with regard to identified technical problems.

The research examinations presented in the paper have been carried out in the chosen manufacturing enterprise of the plastic industry dealing with cleaning products manufacturing. Research period includes data obtained within 8 weeks. Products are made of polyurethane foam containing the abrasive non-woven fabric or polyurethane foam massage that has a density of $21 / 23 \mathrm{~kg} / \mathrm{m}^{3}$ in 5 different colours is used in the ana- lyzed manufacturing process. The produced foam is certified. The nonwoven fabric abrasive has a basis weight of $550 \mathrm{~g} / \mathrm{m}^{2}$.

Individual operations marked with numbers are as follows (in parentheses there are identified operations' duration):

1.The unloading of ordered raw material from a lorry. 2. The qualitative and quantitative control of raw materials taken to the warehouse. 3. Transport of raw materials by a forklift to place of materials' storage. 4. Storage of materials. 5. Preparation of stored materials for the production on the basis of the supplied production order. 6. Transport of materials from the warehouse to the production hall by a forklift truck. 7.The inspection of delivered raw materials by the foreman. 8. Transport of materials to the first stage of the horizontal cutting machining by a forklift truck. 
9. The operation of the horizontal materials (polyurethane foam blocks) cutting with the panel dimension control and record of the measurement result 10. Transport of the cutting raw material on pallets to the next production stage. 11. The bonding operation of cut material cut with non-woven abrasive material, hooking of the glued pallets with simultaneously administered glue weight control and record of control results. 12. Transport of a glued material to the glued pallet storage. 13. The storage of glued materials at the production place to ensure adequate conditions for the binding glue process. 14. The operation of glued pallets unfastening. 15. Transport of materials for vertical cutting station. 16 . The vertical cutting operation of the material and the dimensions control of the cut material and record of the control results. 17. Transport of the cut material to the packing station. 18. The packing operation with visual control based on the product model. 19. Transport of the finished product to the place of temporary storage, which is a place of constant control. 20. The sampling control carried out by quality controller. 21. Transport of the finished product to the warehouse. 22. Preparation of the pallet with the finished product for a storage. 23. Transport of the finished product to the storage. 24. The storage of the finished product.

\section{Methodology of research}

The research analysis was conducted with applying the machines maintenance conditions assessment based on Technology ABC method (BORKOWSKI S., Selejdak J., Salamon Sz. 2006). The Technology $\mathrm{ABC}$ methodology allows specifying the modernity level of individual components parts in the chosen machine. Presented research methodology is based on the principle related to the fact, that each group of machine's components are divided into several groups marked with the letter A (affect on the main manufacturing results). There are also some machine's components that are marked with the letter $\mathrm{C}$ (have a small contribution to the manufacturing results and the machines maintenance conditions). The other parts of groups are marked with the letter B (BORKOWSKI S. 2004).

Application of $\mathrm{ABC}$ analysis allows identifying of significant technological capabilities of enterprises' machines responsible for the final quality performed by the manufacturing processes (BORKOWSKI S. 2012). Technology ABC analysis is applied with using Parker scale (5 grading scale).

Research findings on chosen machine's modernity level have been analyzed in the context of machines' maintenance conditions by applying calculations on the Overall Effectiveness Efficiency of the Machine (OEE) that is a key measure of Total Production Maintenance. The Overall Effectiveness Efficiency of the Machine is a measure of the machine efficiency that is calculated based on its performance (BORKOWSKI, S., JEZIORSKI, L., RYCHTER, A. 2004).

\section{Results and discussions}

Table 1 presents an assessment of the individual machine components modernity level carried out with using the $\mathrm{ABC}$ method for the machine of Techno pak FP 05 type, that was produced in 1994.

Table 1. Assessment of the machine parts modernity level for Techno pak

\begin{tabular}{|c|c|c|c|}
\hline $\begin{array}{l}\text { Subas- } \\
\text { sembly }\end{array}$ & No & $\begin{array}{c}\text { Parts/Components } \\
\text { of the machine }\end{array}$ & $\begin{array}{c}\text { The modernity } \\
\text { level }\end{array}$ \\
\hline \multirow[b]{5}{*}{ A } & A1 & Control system & 2 \\
\hline & $\mathrm{A} 2$ & Console & 1 \\
\hline & $\mathrm{A} 3$ & $\begin{array}{l}\text { Gear (changing a length of the } \\
\text { package) }\end{array}$ & 3 \\
\hline & A4 & Drive motors & 3 \\
\hline & A5 & Sprockets & 3 \\
\hline \multirow[b]{9}{*}{$\mathrm{B}$} & B1 & Main propulsion system & 3 \\
\hline & $\mathrm{B} 2$ & Drive train feed & 3 \\
\hline & B3 & $\begin{array}{l}\text { Pneumatic system of heaters } \\
\text { shutdown }\end{array}$ & 3 \\
\hline & B4 & Electric heating system & 3 \\
\hline & B5 & The drive system of sealing rollers & 3 \\
\hline & B6 & The team of guide rollers & 4 \\
\hline & B7 & $\begin{array}{l}\text { Team rolls of tape leading } \\
\text { to the repeller }\end{array}$ & 4 \\
\hline & $\mathrm{B} 8$ & Feeder chain to sponges running & 4 \\
\hline & B9 & Chains & 4 \\
\hline \multirow[b]{4}{*}{ C } & $\mathrm{C} 1$ & The machine construction & 4 \\
\hline & $\mathrm{C} 2$ & Covers of the moving parts & 5 \\
\hline & $\mathrm{C} 3$ & Platen & 4 \\
\hline & $\mathrm{C} 4$ & Control valves & 3 \\
\hline
\end{tabular}

Source: own study based on internal materials of the enterprise. 
Parts located in different components (Table 1), can be qualified in accordance to Parker scale:

- A in $60 \%$ is identified on 3 level and two others (20\%) - on 2 and 1 level,

- $\mathrm{B}$ in $55,5 \%$ is identified on 3 level and $45 \%$ - on 4 level,

- $\mathrm{C}$ in $50 \%$ is identified on 4 level and $25 \%$ - on 5 and 3 levels.

As a result of research analysis based on Technology $\mathrm{ABC}$ method, that 18 parts in the analyzed machine is characterized as follows:

- 1 is on the level 1 in Parker scale,

- 1 is on the level 2 in a Parker scale,

- 9 is on the level 3 in Parker scale,

- 6 is on the level 4 in Parker scale,

- 1 is on the level 5 in Parker scale.

On the basis of the analysis, it can be stated, that modernity level of the analyzed machine parts is identified between 1 and 5 level in Parker scale with the majority of those parts identified in the range: $3 \div 4$ level.

The research findings on the machines modernity level in the analyzed enterprise dealing with plastic products manufacturing shown that analyzed ma- chines' components are modern, what can be directly reflected to high product quality level. It has been also confirmed as the result of analysis that concerned nonconformities identified in the packaging. It was stated, that within two months the analyzed machine packed 44417 pieces and there were identified 3566.7 pieces of nonconformities, what is $0.81 \%$ of nonconformities at all.

Analysis of the machines' maintenance conditions based on TPM coefficients assessment have been presented with applying of OEE analysis. The calculation of OEE coefficients for chosen machines maintenance conditions assessment are presented in Table 2.

Figure 1 presents analyzed coefficients that are following: the quality coefficient, the overall machines efficiency coefficient and the use coefficient.

As it results from the analysis of data presented in Table 2 and Figure 1, the value of OEE coefficient is highly variable $(34.87 \% \div 81.16 \%)$. These values have a large range. It can be concluded, that obtained research findings are caused by unplanned machines breakdown and stops. In majority of obtained research results, OEE coefficient is assessed as a high nominally (in the range: $74.31 \% \div 81.16 \%$ ).

Table 2. Techno pak efficiency analysis for 8 weeks

\begin{tabular}{|c|c|c|c|c|c|c|c|c|c|c|c|c|c|c|}
\hline 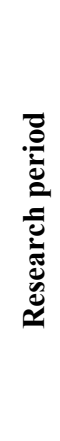 & 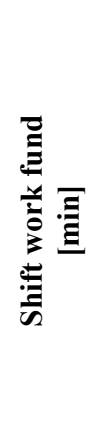 & 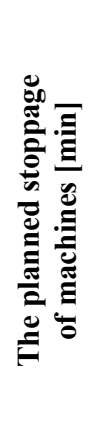 & 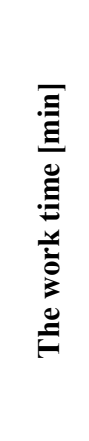 & 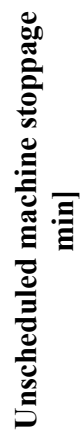 & 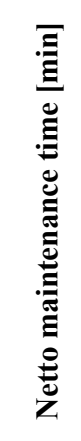 & 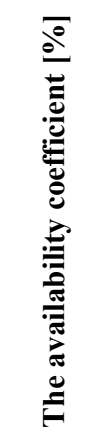 & 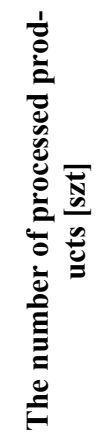 & 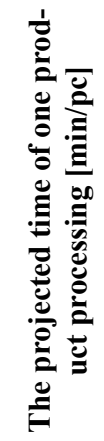 & 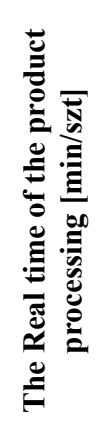 & 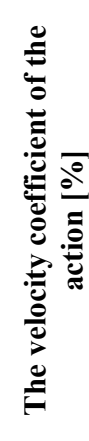 & 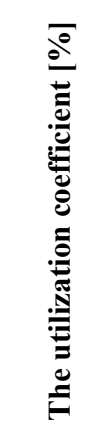 & 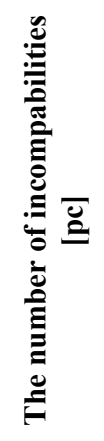 & 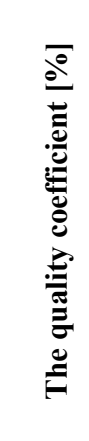 & 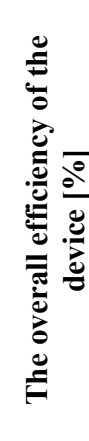 \\
\hline 1 & 4320 & 885 & 3435 & 845 & 2590 & 75,40 & 36592 & 0,033 & 0,071 & 46,62 & 46,62 & 295,7 & 99,19 & 34,87 \\
\hline 2 & 4800 & 2315 & 2485 & 330 & 2155 & 86,72 & 66154 & 0,033 & 0,035 & 94,29 & 101,30 & 613 & 99,07 & 81,16 \\
\hline 3 & 4800 & 3400 & 1400 & 250 & 1150 & 82,14 & 32284 & 0,033 & 0,036 & 92,64 & 92,64 & 400 & 98,76 & 75,16 \\
\hline 4 & 4800 & 2740 & 2060 & 415 & 1645 & 79,85 & 47434 & 0,033 & 0,035 & 95,16 & 95,16 & 494,7 & 98,96 & 75,19 \\
\hline 5 & 3840 & 120 & 3720 & 435 & 3285 & 88,31 & 77944 & 0,033 & 0,042 & 78,30 & 78,30 & 256,6 & 99,67 & 68,92 \\
\hline 6 & 4800 & 2310 & 2490 & 215 & 2275 & 91,37 & 56337 & 0,033 & 0,040 & 81,72 & 81,72 & 270 & 99,52 & 74,31 \\
\hline 7 & 4800 & 1880 & 2920 & 310 & 2610 & 89,38 & 68132 & 0,033 & 0,038 & 86,14 & 86,14 & 849,2 & 98,75 & 76,04 \\
\hline 8 & 4800 & 1540 & 3260 & 280 & 2980 & 91,41 & 59108 & 0,033 & 0,050 & 65,45 & 65,45 & 387,5 & 99,34 & 59,44 \\
\hline
\end{tabular}

Source: own study based on internal materials of the enterprise 


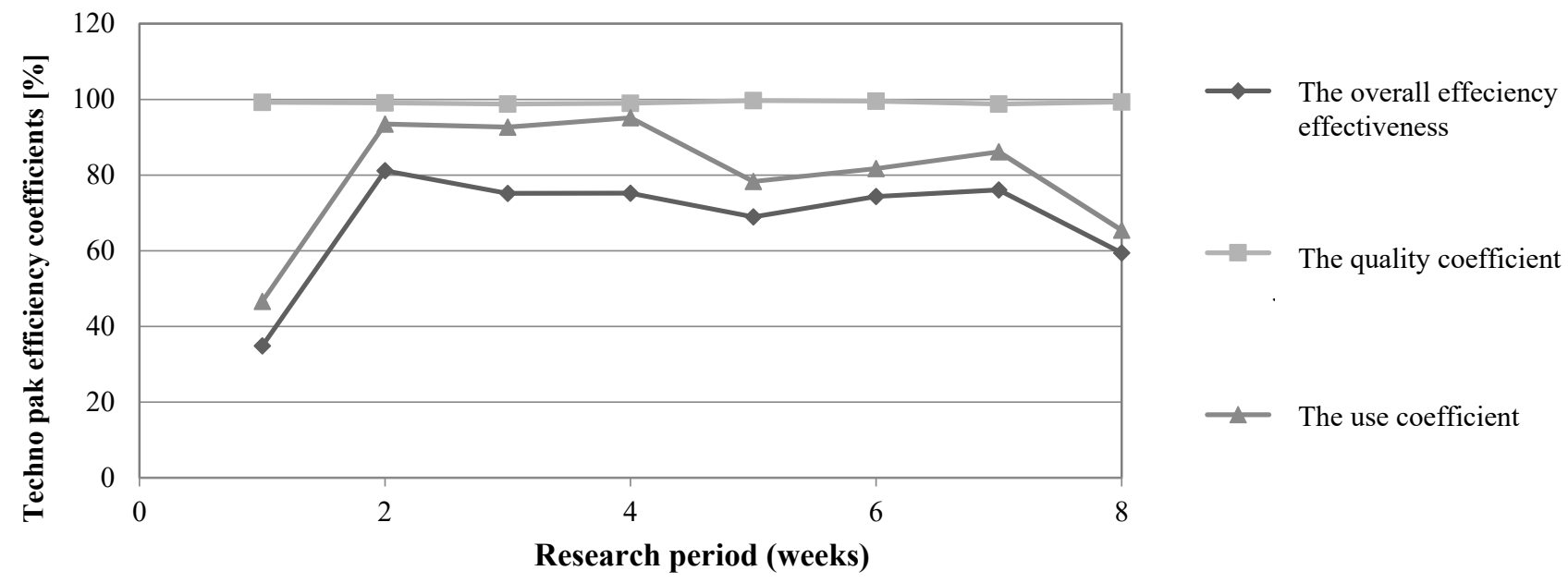

Fig. 1. Comparison of Techno pak efficiency coefficients in the research period 8 weeks.

Source: own study based on internal materials of the enterprise.

Research findings presented in Figure 1 shown, that the quality coefficient is characterized by high level and it is stable. The other coefficients are in the range: $40 \% \div 98 \%$.

\section{Summary and conclusions}

Presented research paper presents research examinations results that concerns machines' maintenance conditions assessment based on TPM coefficients analysis. The overall efficiency (OEE) for packaging machine Techno pak fluctuated within two months (8 weeks) in the range $34.87 \% \div 81.6 \%$. In most cases the OEE coefficients amounted high values $(74.31 \% \div$ 91.16\%).

An evaluation of the modernity machine components' level of the packaging machine was conducted in accordance to technology $\mathrm{ABC}$ method with applying Parker scale. On the basis of the obtained research findings, it can be stated, that the machine's components are evaluated between 1 and 5 level of Parker scale with the majority of parts identified on level 3 and 4. As it results from above research results, most of the component parts are assessed as modern components and it is reflected to product quality level. It has been also confirmed in the results of the nonconformities analysis results for the packaging process, because within two months analyzed machine packed
44417 pieces and in that period there were identified $3,566.7$ of nonconformities $(0.81 \%)$.

\section{Additional information}

This work is connected to the scientific program of the „Improving quality of processes, products and services" BW 615/201/07. This project is supported by the Polish Ministry of Science and Higher Education.

\section{Literature}

1. Borkowski S., JEZIORSKI L., RYCHTER A. 2004. Zarzadzanie czasem pracy maszyn $w$ ramach TPM. Wydawnictwo Wyższej Szkoły Zarządzania i Marketingu. Sosnowiec.

2. Borkowski S., Selejdak J., Salamon Sz. 2006. Efektywność eksploatacji maszyn i urządzeń. Wydawnictwo Wydziału Zarządzania Politechniki Częstochowskiej. Częstochowa.

3. Borkowski S. 2004. Mierzenie Poziomu Jakości. Wydanie I Sosnowiec.

4. BORKOWSKI S. 2012. Tradycyjne narzędzia zarzadzania jakościa. Teoria i praktyka. Oficyna wydawnicza Stowarzyszenia Menadżerów Jakości i Produkcji. Częstochowa. 